\title{
Speculation, segregation and (absence of) conflicts: In the production of the urban space of Palmas / TO

\author{
Ana Carla de Lira Bottura
}

\section{Ana Carla de Lira Bottura}

PhD student at IAU-USP; Master in Urban Anthropology; Teacher at FAPAC / Porto Nacional; acclira@gmail.com

\begin{abstract}
This article introduces partial discussions from a doctoral research in progress that has as object of study the tendency to pacification and concealment of conflicts verified in the production process of contemporary urban space - particularly in the most recent Brazilian cities - as well as its strategies and mechanisms of control. As a field of study, it is proposed the city of Palmas, capital of Tocantins, last planned capital of the twentieth century, founded on May 20, 1989, a year that symbolizes the opening of the Western world to the neoliberal economic policy. Based on the observation of the absence of significant movements of resistance to the urban space production process at Palmas and interpreting it as a reflection of pacifying tendency of consensus and appeasement / masking of conflicts as a feature of neoliberal city, we propose the hypothesis of physical and territorial configuration of the city as a laboratory of the neoliberal model of urban management, in which socio-spatial dynamics gradually developed in other contemporary cities through processes historically constructed, get explicit and take place, immediately or in a very short time. Through a historical approach to the context of its creation and occupation, we propose an urban space production reading based on the recognition of characteristics relating to its conditions of New Town and neoliberal city as well as the incipient action of the social movements dedicated to the struggles for housing as social agents in this process.
\end{abstract}

Keywords: urban space production, socio-spatial segregation, Palmas/TO.

\section{Resumo}

O presente artigo introduz discussões parciais da pesquisa doutoral em andamento que tem como objeto de estudo a tendência à pacificação e ocultação de conflitos verificadas no processo de produção do espaço urbano contemporâneo - em específico nas cidades brasileiras mais recentes - bem como suas estratégias e mecanismos de controle. Como campo de estudo, propõe-se a cidade de Palmas, capital do Tocantins, última capital planejada do século XX, fundada em 20 de maio de 1989, ano que simboliza a abertura do mundo ocidental à política econômica neoliberal. Tomando como base a observação da ausência de movimentos expressivos de resistência ao processo de produção do espaço urbano em Palmas e interpretando-a como um reflexo da tendência pacificadora de estabelecimento de consensos e apaziguamento/ocultação de conflitos característica da cidade neoliberal, elabora-se a hipótese da configuração físico-territorial da cidade enquanto um laboratório do modelo neoliberal de gestão urbana, no qual se explicitam e se realizam, de maneira imediata ou em tempo reduzido, dinâmicas socioespaciais desenvolvidas gradualmente nas demais cidades contemporâneas, através de processos historicamente construídos. Através de uma abordagem histórica do contexto da sua criação e ocupação, propõe-se uma leitura da produção do espaço urbano com base no reconhecimento de 
características relativas às suas condições de Cidade Nova e de cidade neoliberal, bem como da atuação incipiente dos movimentos de luta pela moradia enquanto agentes sociais deste processo.

Palavras-chave: Produção do espaço urbano, segregação socioespacial, Palmas/TO.

Resumen

En este artículo se presenta una discusión parcial de la investigación de doctorado en curso que tiene como objeto de estudio la tendencia a la pacificación y la ocultación de los conflictos verificados en el proceso de producción del espacio urbano contemporáneo - en particular las más jóvenes ciudades brasileñas - así como sus estrategias y mecanismos control. Como campo de estudio, se propone la ciudad de Palmas, capital de Tocantins, última capital planificada del siglo XX, fundada el 20 de mayo de 1989, un año que simboliza la apertura del mundo occidental a la política económica neoliberal. Basándose en la observación de la ausencia de movimientos significativos de resistencia al proceso de producción del espacio urbano de Palmas e interpretándole como un reflejo de la tendencia pacificadora de establecimiento del consenso y el apaciguamiento/ocultación de conflictos característicos de la ciudad neoliberal, se establece la hipótesis de la configuración física y territorial de la ciudad como laboratorio del modelo neoliberal de gestión urbana, en la que se explicita y se lleva a cabo, de manera inmediata o en un corto período de tiempo, dinámicas socio-espaciales que se desarrollan gradualmente en otras ciudades contemporáneas a través de procesos construidos históricamente. A través de una aproximación histórica al contexto de su creación y ocupación, se propone una lectura de la producción de espacio urbano basado en el reconocimiento de las características relativas a sus condiciones de Ciudad Nueva y ciudad neoliberal, así como la acción incipiente de movimientos de lucha para la vivienda como agentes sociales en este proceso.

Palabras-clave: Producción del espacio urbano, segregación socio-espacial, Palmas/TO.

\section{Introduction}

This article presents partial discussions of the ongoing doctoral research that aims to study the tendency towards pacification and concealment of conflicts verified in the process of production of the contemporary urban space - specifically in the most recent Brazilian cities - as well as its strategies and mechanisms of control.

As a field of research, the city of Palmas, capital of Tocantins, the last planned capital of the 20th century, is proposed. Founded on May 20, 1989 - a year that symbolizes the opening of the Western world to neoliberal economic policy - and thus conceived in a world already undergoing reorganization to serve the global financial market, Palmas today, at the age of 27, presents a segregationist profile similar to that identified in unplanned cities, with a disorderly occupation that favors free real estate speculation and concentration of the poverty in peripheral areas, lacking urban infrastructure and public services. 
1 According to Trevisan (2009), these are urban nuclei identified from a particular arrangement of six elements: a) created by the desire of the public power or private initiative and concretized in specific actions; B) that seek to attend to one or more dominant functions (administrative, colonization, railway, satellite, etc.); C) deployed in a previously chosen site; D) from an urban project; E) elaborated and / or developed by defined agent (s) - if applicable professional (s); And f) within a certain time limit, implying even at a reasonably precise moment of foundation. (TREVISAN, 2009, 14)
In order to do so, it is understood that the study of the conflict (or its fragility) in the city demands the consideration of some complementary facts between them, which, finally, are exploratory fields of great importance for the development of the research: 1) we're talking about an administrative New City ${ }^{1}$, whose creation is inserted in the context of expanding the borders of accumulation of capital in the interior of the country; 2) the world political and economic situation in the historical period of its birth is clearly reflected in the most diverse dimensions of its conformation (territorial, social, political, etc.), understood here as a neoliberal city; and 3) the punctual and poorly articulated action of local social movements is intrinsically related to the two previous events, which constitute a condition of the social agents acting in the process of urban space production.

Without the intention of exhausting the long discussion that the diverse subjects treated here deserve, the present article presents preliminarily identified aspects related to these three axes, having as main objective to raise and to expose discussions in embryonic phase, to be expanded during the development of the mentioned search.

It is important to emphasize that the use of the term "absence of conflict" proposed here should not be understood as a lack of recognition of the existing struggle of local social movements, but rather as an identification of their fragility and inability to oppose the sovereignty of the neoliberal project that permeates all historic of the creation of Palmas, and even of the state of Tocantins, as discussed below.

\section{A new capital for a new state}

The foundation of Palmas is directly linked to the creation of the state of Tocantins and to the figure of the Brazilian politician José Wilson Siqueira Campos, whose deep admiration for Juscelino Kubitschek guided the premises under which the construction of the capital of the new Brazilian state was idealized.

The geographer Elizeu Lira (2011) identifies the foundations of the creation of Tocantins, some of which seem to us extremely important for the understanding of the regional political context in which the creation of Palmas is inserted. From the beginning of the twentieth century, the author highlights a succession of efforts undertaken by the Brazilian government, supported by foreign capital, especially the American capital, in order to expand the model of capitalist development 
already consolidated in the current southeast region of the country towards the amazonic region and the western part of the country. The March to the West, idealized in the Vargas government during the 1930s, represented the first great government policy of coIonization of the Cerrado region. Under the discourse of modernization and in order to create the conditions to adjust the country to a new rate of capitalist production, the March presupposed the expansion of the road network in the Midwest, the creation of new economic and agricultural frontiers, new migratory flows of demographic occupation, new cities, among others (PELÁ \& BARREIRA, 2013, p.40). The idealization and construction of the city of Goiânia, which began in 1933 , is part of these actions and investments directed to the development of the region, whose intensification will culminate with the construction of Brasília (1960), followed by the Belém-Brasília Highway and, later, the creation of Palmas (1989).

Lira (2011) also points out, as part of development policies linked to international capital, the insertion of the territory of Tocantins within the limits of the Legal Amazon ${ }^{2}$, which in the author's point of view "é uma região criada pelos governos militares e/ou paramilitares, com o intuito de reafirmar a soberania nacional na região e desenvolvê-la de maneira 'segura' ". (LIRA, 2011, p.29)

Thus, through the creation of laws, agencies and superintendencies aimed at the development and valorization of the Amazon, the establishment of agricultural colonies in charge of guiding settlements in the Cerrado region and programs and development plans, the Brazilian government set out its strategy of internalization Country, opening roads in the North and Central West for the expansion of capital via modernization of the territory. In this sense, the Belém -Brasília Highway played a fundamental role in the occupation and urbanization model that occurred in northern Goiás, which witnessed the rapid growth and emergence of cities along its banks, directly linked to this modernizing capital.

According to Trevisan (2009), the creation of New Cities (CNs), in a general way, is aligned directly with development strategies of mainly economic features: "Economicamente, as CNs servem como instrumento de multiplicação do capital. São tidas como investimentos diretos e indiretos na obtenção de lucros por seus empreendedores." (TREVISAN, 2009, p.105-106)
2 The concept created by the Brazilian government, through Law 1,806 of January 6,1953 , which delimits an area that encompasses nine states belonging to the Amazon Basin (Acre, Amapá, Amazonas, Pará, Rondônia, Roraima, Tocantins, Mato Grosso and part of the state Of Maranhão), under the argument of promoting an integrated regional and economic development plan for the Amazon region. The area occupied by the Legal Amazon corresponds to approximately $61 \%$ of the entire Brazilian territory. 
3 Karl Marx, "Gundrisse", cit., p.445.

It is observed, therefore, that the foundation and construction of New Cities (and also of new states) are products of the same principle whose purpose is the amplification of the opportunities of reproduction of capital, as Harvey explains (2011):

O princípio número um é que todos os limites geográficos da acumulação do capital têm que ser ultrapassados. O capital, Marx escreveu nos Grundrisse ${ }^{3}$, "tem de se empenhar para derrubar toda barreira local do intercâmbio, i.e., da troca, para conquistar toda a Terra como seu mercado. (HARVEY, 2011, p.128-129)

It is important to point out that these so-called modernizing actions presuppose significant social transformations in a predominantly rural reality, with the replacement of old farms by agribusinesses and the gradual introduction of mechanization, making cities, and especially new ones, the main territorial management centres. The consequence of this dynamic is the forced migration of thousands of families who lived from work on the land to the peripheries of urban centres.

\begin{abstract}
Essa é a origem das contradições e dos conflitos no/ do território do processo inicial da construção das cidades de Goiânia e Brasília, que mais tarde serão repetidos em Palmas. A bem da verdade, o espaço oficial dessas cidades não foi planejado para a fixação da classe trabalhadora, mas para acolher a nova elite urbano-industrial, necessária à implantação do projeto de modernização do território. (Pelá \& Barreira, 2013, p.49)
\end{abstract}

It's observed, thus, in this process of colonization on a regional scale, the complete absence of social policies that prioritize the insertion of the families deprived of their livelihood in the countryside, transforming themselves into cheap labour in the urban environment. Inversely proportional to the attention given to this class of workers, it was the increase of the concentration of land and accumulation of capital benefiting a few investors.

The separation of Northern Goian and consequent creation of the state of Tocantins is justified, in the first instance, by its historical isolation and difficulties of integration with the south of Goiás. Finally realized in 1988, under the political tutelage of Siqueira Campos, it signify the result of a process that, although heterogeneous and discontinuous, represented the will of the population of Tocantins and the opening of new possibilities for local development. 


\section{Capital of free enterprise}

Palmas was implanted in the geographical centre of Tocantins, in an area chosen for presenting the best physical conditions for the construction of the new capital and for being a poorly developed region. The lands on which the city was established were expropriated from local ranchers by the state, and they were offered small amounts of money, which gave rise to discontent among the owners, leading to a violent eviction case led by the Police (LIRA, 2011, p.192). Purchased as rural land - and therefore evaluated according to parameters compatible with that condition - however transformed by the State into urban lots and sold as such, in a trick that, while prejudicing the former owners, generated revenue for the coffers The public. (TEIXEIRA \& FILHO, 1991)

Thus, Palmas is born with the peculiar characteristic of having the State at the same time as owner of the urban land, its first speculator and in charge of the sales, acting in consortium with big businessmen of all the country and private companies of real estate development and causing that The occupation of urban land had always been intrinsically linked to the real estate market. "Palmas foi apresentada ao capital internacional e/ou nacionalizado como o "novo lugar" do neoliberalismo, onde poderia ser engendrado esse 'novo' modelo de (re) ocupação territorial do capital privado na Amazônia Legal (...)". (LIRA, 2011, p.26)

The last projected capital of the twentieth century (SILVA, 2010) was conceived by a team headed by architects Luiz Fernando Cruvinel Teixeira and Walfredo Antunes de Oliveira Filho, members of the Grupo Quatro office, with an urban area of 11,085ha and expansion areas to the north and to the south that add up to 9,494 ha, with the capacity to house a population of more than 2 million inhabitants (TEIXEIRA \& FILHO, 1991). The city plan is often interpreted as a "copy" of Brasília, an affirmation that Silva (2010) refutes when analysing the different aspects that differentiate Palmas from the capital of the Federal District, such as the absence of a homogeneous zoning of activities, the flexibility of land use and the architectural typologies within the blocks - which have nothing to do with the essence of the Brazilian superquadras - differences in the hierarchy of the road system and, above all, in the complete absence of control at the process of occupation of the city, an aspect that we are interested to highlight here.

The Palmas Master Plan provided for an orderly occupation, to be carried out in stages - starting from 
the central region of the city - as the population foreseen for each stage was reached, culminating with the occupation of the expansion areas in the vicinity of the planned city, only when the population exceeds 1 million inhabitants (it is noteworthy that the population estimated by IBGE for 2104 was only 265.909 inhabitants). In an interview with Hugo Segawa, published in the magazine Projeto in 1991, the authors of the plan speak of the misrepresentation of its initial premises by Siqueira Campos, governor of the state:

Por razões que para nós não são claras, o governo resolveu abrir frentes de ocupação de maneira diferente daquela planejada, doando lotes em áreas afastadas da parte central da cidade para migrantes. Na realidade, o governo fez uma distinção entre pessoas de maior e menor poder aquisitivo. Na cabeça deles parece que não entrou o conceito de que as diversas classes sociais eram indistintas para efeito do plano: você tem que abrigar todas. (TEIXEIRA \& FILHO, 1991, p.107)

It is worth mentioning that the first Siqueira Campos government in the state of Tocantins was a provisional administration of two years until the next elections, and it was marked by the slogan "twenty years in two", in an explicit reference to the speech of Juscelino Kubitschek respect to Brasília ("fifty years in five"). This presupposes the imposition of an excessively accelerated pace on all decisions, projects, constructions, etc. Efforts focused mainly on consolidating Tocantins through the creation of the new capital as the administrative seat and ensuring that Palmas developed and continued to be built and populated in the way he had idealized it. The threat of discontinuity of his administration in the 1990 elections is pointed out as the main cause of the total lack of control in the occupation of blocks that supposedly would be inhabited in very advanced phases of the urbanization of the city. Before handing over the government to his successor, Moisés Avelino, Siqueira distributed thousands of lands on a lending basis, with the intention that the city be occupied and consolidate quickly, thus avoiding the setback of his work. This distribution of lots followed a segregationist logic of implantation of more affluent and influential classes in the central region of the city, followed by civil servants from the highest to the lowest step in a decreasing vector in the south direction. Poor families who came to the city in search of jobs and opportunities were allocated lots in the expansion areas, outside the planned urban network, in the neighbourhoods known as Taquaralto and Aurenys. (SILVA, 2010, p.99)

À classe trabalhadora - imprescindível à construção, consolidação e manutenção dessas cidades, para a formação da 
massa trabalhadora urbana e para a consolidação do projeto de expansão do capital via modernização do território - foram, e ainda são, reservados espaços não oficiais, ou seja, os espaços segregados e periféricos. (PELÁ \& BARREIRA, 2013, p.49)

The result was very rapid and with irreversible consequences: in just two years, Palmas had become a disorderly city, full of urban voids (since most of the lots donated became areas of real estate speculation), built without any type of effective supervision, clearly segregated, with serious problems of urban infrastructure and lack of public facilities in the poorest areas. That is, common issues to any other Brazilian city. And here too we saw the use of the Master Plan as an instrument, not of territorial planning, but of support to political strategies that had little relation with the original intentions of its authors.

\section{In pursuit of social justice}

When arriving at the city through the Fernando Henrique Cardoso Bridge, the traveller is faced with a sign that reads "Tocantins: State of Free Initiative and Social Justice," slogan created in the third term of governor Siqueira Campos (1999-2002), still present in the local political imagination, perhaps as a goal to be achieved, perhaps as a mere advertising strategy. What is certain is that the phrase itself is contradictory while trying to unite two categories so far apart that they can almost be taken as antonyms: is it possible the existence of social justice in the place where free enterprise prevails?

As would be expected, in the capital with the highest index of geometric population growth in the country ${ }^{4}$, the socio-spatial segregation that was born as Palmas was being built only got intensified over the years. The creation of popular settlements on the outskirts of the city under the tutelage of the State (Aurenys I, II, III and IV) allowed for the proliferation of other popular settlements besides Taquaralto (Santa Fé, Setor Sul, Bela Vista, etc.), irregular occupations (Santa Bárbara, Sol Nascente, Morada do Sol, Irmã Dulce, etc.), besides several other forms of improvised housing, such as tenements scattered around the Plan. (MIRANDA, 2005)

The first case of subversion to the Siqueira's logic of territorial occupation occurred in the early years of the city's foundation, when, under the government of Moisés Avelino, blocks 303, 305 and 307, all to the north, were occupied by hundreds of families And started a process of struggles and negotiations that resulted
4 According to IBGE data, 2014. 
in the first popular neighbourhood to be consolidated within the limits of the planned city, Vila União, which now houses around 21 thousand inhabitants, equivalent to approximately $8 \%$ of the population of the whole city.

Throughout its short history, Palmas has been gradually building bases of resistance and struggle for housing, through the actions of local urban social movements, some of them linked directly to organizations on a national scale, such as the MNLM (National Movement for Struggle for Housing), The MTST (Movement of the Homeless Workers), the MNMP (National Movement for Popular Housing), the FACOM-TO (Federation of Community Associations and Residents of Tocantins), the MILM (Independent Movement for Housing), OPM (Popular Housing Organization), among others. Its guidelines have focused mainly on the occupation of idle lots and on various forms of negotiation with the government with a view to the donation of areas, construction of social housing projects, public facilities and improvements in the urban infrastructure of the peripheral neighbourhoods. However, it is observed that, despite the efforts made by the leaderships until then, these movements are still acting in a disjointed and ineffective way.

In a study about the actuation of three social movements for housing struggle, Suzuki (2016), reports in details the history of occupations, negotiations, achievements and frustrations of these social agents, in order to prove the importance of recognizing and valuing their presence in the production of the local urban space. However, it does not take too much of an analysis to realize that urban areas destined or conquered by social movements are located almost entirely in peripheral areas of the Master Plan region, or even outside of it. In this fact, what deserves a more careful observation (and which still lacks the formulation of a response) is not the intention of the government to yield to the popular pressures for the regularization of certain occupations, but rather the identification of a tendency of the movements to dispute spaces located in areas far from the centre of the city, mostly lacking in infrastructure and urban equipment and of little real interest. While it is recognized that such a strategy is more likely to be successful from the point of view of the conquest of housing, it is acknowledged that this behaviour tends to reinforce the sovereignty of the real estate market, while restricting the potential of social movements as agents of transformation. Among the readings that may derive from this fact, to be verified in later stages of the research, one points to a possible 
avoidance of audacious strategies of direct confrontation due to a low coping capacity registered by the movements in their current conditions of action.

In this sense, another aspect raised by Suzuki (2016) that we must emphasize here concerns the mechanisms used by the municipal government to weaken the struggle for housing, either through persuading leaders to take positions in public agencies of the city , the criminalization and delegitimation of occupations as organizations or the fragmentation of these through repossessment actions.

Thus, without strong enough resistance forces to face the action of free initiative widely supported by the State, we are witnessing the full realization of the homogenizing and pacifying tendencies inherent in the process of production of the neoliberal city ${ }^{5}$. It is understood, therefore, that there is in Palmas a weakness of conflicts representative of the class struggle that contributes to the maintenance and the naturalization of the socio-spatial inequalities existing from the first years of its foundation.

\section{Notes on the production of urban space in Palmas}

The production of space is established as a condition, medium and product of the reproduction of society, through a dialectical relationship in which one is realized in the other and through the other, transforming it to the step whereby it is transformed by it. According to Carlos (2016, p.58), "a compreensão dos conteúdos da produção do espaço urbano pode aparecer como condição necessária para iluminar os conflitos que residem no seio da sociedade." Considering the capitalist orientation of social production, it is understood that the production of urban space is embedded in this same logic, which transforms all production into merchandise. In this context, it 's possible to identify a contradiction: although the production of space takes place socially, its appropriation is private, "pela mediação do mercado imobiliário, fazendo vigorar a lógica do valor de troca sobre o valor de uso". (Idem, p.60)

The author also identifies, as subjects of action: the State, as the subject of political domination; The capital (industrial, commercial and financial, including its articulation with the real estate market), with its strategies aiming at the continuous reproduction; and social subjects, who, having the realization of human life as the ultimate goal, have space as a condition, medium and product of their action. From a similar
5 See Rancière $(2009,1996)$. 
classification Corrêa (2016, p.45) highlights the multiple roles of the State, understanding it as "an arena in which different interests and conflicts are faced" and admitting the frequent mechanisms of negotiation, cooptation and clientelism that this relationship favours.

A preliminary reading of Palmas and its process of production of urban space allows us to observe the precocity with which some contemporary phenomena are established in the intra-urban space, constituting themselves as guiding principles of its own construction. With regard to the phenomenon of the constitution of the city as a commodity, here we find the state itself as the first speculator and centrepiece in the organization of the local real estate market, by dispossessing rural lands, negotiating them as overvalued urban lands, and keeping to the present day a stock of urbanized areas in areas of increasing appreciation. We can also recognize the strategies of the city-merchandise in the successive debates about the expansion of the urban perimeter, leveraged by a strong political pressure exerted by the real estate sector, eager to expand its fields of activity (BAZOLLI, 2011). In discussing the close relationship between capitalist development and urbanization, Harvey (2014) argues that the processes of urban transformation and expansion, as well as the accompanying real estate speculation, play a key role in balancing the global market through the absorption of surplus products, vital to maintaining the system itself. Strongly connected to the strategies of neoliberal capitalism, the movement of expansion, construction or reconstruction, remodeling, revitalization, restructuring of cities (among other "modalities" of intervention), with a view to increasing competitiveness on the international scene, reinforces the thesis that Palmas was constituted, from its beginnings, in " mercadoria a ser vendida, num mercado extremamente competitivo, em que outras cidades também estão à venda". (VAINER, 2009, p.78)

${ }^{6}$ See Vainer (2009).

Analyzing from the perspective of the city-company 6 , it is observed that, in Palmas, there has not been a gradual process of association between public and entrepreneurial power, it is configured as a primordial condition to its creation: the viability of the city necessarily passes through the relations of partnership between public-private capital, through which all the initial basic urban infrastructure (water supply, electricity, hospital and others) was built, as well as in any real estate development process (LIRA \& CARVALHEDO, 2009), in order to influence the principles of segregationist occupation adopted by the State. The 
self-constructed image of the "free initiative state" already makes explicit the entrepreneurial profile and the intention to attract external investors, characteristic of Siqueira Campos administration:

\begin{abstract}
Peculiar em Palmas foi o discurso institucionalizado e veiculado pela mídia de que a cidade seria o "lócus" por excelência da iniciativa privada e empresarial. Assim a cidade trabalha para criar infraestruturas físicas para atrair os capitais dispostos a ali investirem. (MELLO \& BERTTONE, 2004, p.72)
\end{abstract}

Born and managed from the start as business, Tocantins' capital has now as the mayor a Colombian businessman - Carlos Amastha - from the mall industry, with no previous political experience. That is, the strategy of urban entrepreneurship is not only present in its foundation, but also consolidates and naturalizes itself as a way of managing the public good.

The consolidation of the popular neighbourhoods in the peripheral regions, through the donation of lots by the public power, is covered by the discourse of housing policy directed to the poor population - excluded from the city planned for not having enough financial resources for the acquisition of land within its limits - suggesting, thus, an image of "social justice" that camouflages devices of exclusion. The socioeconomic segregated occupation strategy can also be understood as a tactic of control and pacification of public spaces, since: 1 ) the excluded population settled in the peripheries poorly connected through public transportation and endowed with their own structures of commerce and small and medium-sized services tends to restrict travel to the central regions of the city on the basis of work or occasional issues; 2) this same population, in general, today does not sketch any resentment with the clearly segregationist policy that has always been established, because they feel contemplated and satisfied with the government that granted them a lot and, therefore, an opportunity to settle in that New territory.

These and other characteristics identified in the construction of Palmas also show the coexistence between different temporalities in its territory: the city that wants to be formally modern (without being so) is perfectly in harmony with traces of postmodernity 7 that permeates the Historical moment of its creation. The postmodern space-time compression announced by Harvey (1992) - understood as the acceleration in the rhythm of life and the overcoming of space barriers as a consequence of the technological advances produced in the transition from the Fordist produc-
7 According to Silva, V. (2009), the traits of postmodernity in Palmas can be found in the fragmented urban occupation, the urban fabric irregularity, the eclecticism of its architecture, the simulacrum that permeated the attempt to forge an identity for The newly created city. 


\footnotetext{
${ }^{8}$ See Martins (1994).

${ }^{9}$ See Palacin (1990).
}

tion system to the flexible accumulation - In the form of (almost) instantaneous effects on the urban space detached from the historical processes that usually would originate them. This finding, allied to the fragility of the resistance forces mentioned earlier, brings us closer to the metaphorical image of the city of Palmas as a neoliberal city laboratory, in which socio-spatial dynamics that in most contemporary cities are developed gradually, through historically constructed processes - and, therefore, full of internal conflicts - are explicitly and immediately realized, or in short time, without the occurrence of significant obstacles.

The hypothesis of the city of Palmas as a neoliberal city laboratory is based, therefore, on the observation of an apparent absence of expressive forces of resistance to the application of neoliberal policies, be it in the form of practices of counter conduct in the urban space or presence of significant conflicts between social agents, representatives of capital and public power, denouncing the also identified fragility of local urban social movements. However, the laboratory proposed here is that of the "neoliberal Brazilian city," which admits the coexistence of the old with the new, of different forms of urbanity and sociability stemming from the most distinct cultural references that make up its hybrid population and which are reflected, for example, in the vitality of public fairs or in the presence of people talking late in the afternoon sitting in chairs in front of houses in the less elitist sectors of the city. Traces that refer to the interior origins and which are still alive and strongly influential - especially in the relations between the State, the capital and the social subjects - that denounce the persistence of relations clientelism ${ }^{8}$ and coronelismo ${ }^{9}$, intrinsic to its formation as territory and social body.

In this way, it is important to point out that the implementation of the neoliberal project around the world did not take place in a homogeneous and simultaneous way, especially taking as reference the Latin American countries, where different democratizing processes imposed different rhythms and modes of implementation of the measures Neoliberals. The impacts of this movement in Brazil are addressed by Dagnino (2004a) through the identification of the existence of a

[...] confluência perversa entre um projeto político democratizante, participativo, e o projeto neoliberal, que marcaria hoje, desde nosso ponto de vista, o cenário da luta pelo aprofundamento da democracia na sociedade brasileira. (DAGNINO, 2004a, p.95) 
According to the author, the meeting between the process of democratic openness and the conquest of public spaces for the sharing of issues and decisions between the State and civil society in the 1980s and the implementation of the neoliberal adjustment established with the Collor's (1989) government point to opposing and even antagonistic directions. Consequently, we can observe the emergence of a discursive crisis, whose foundations lie in the struggle for meaning around the notions of civil society, participation, citizenship and democracy, strategically displaced, redefined and widely diffused within a neoliberal conception that, while camouflaging conflicts, promotes at the same time reductionism and contributes to the depoliticization of the democratizing project.

\begin{abstract}
Assim, o projeto neoliberal operaria não apenas como uma concepção de Estado mínimo, mas também com uma concepção minimalista tanto da política como da democracia. Minimalista, porque restringe não apenas o espaço, a arena da política, mas seus participantes, processos, agenda e campo de ação. (DAGNINO, 2004b, p.159)
\end{abstract}

The discussion that is proposed here is part of the consideration of the generalized preexistence in Brazil of a political scenario of democratic transition, which has promoted a gradual growth and maturation of participatory experiences, thus constituting a field of dispute and, therefore, enabling development of perverse confluence. However, an approach to the specific context of a new city, whose foundation coincides with the implementation of the neoliberal project, allows the observation of nuances that escape the general interpretation of this confluence. That is, considering the conformation of the social body of Palmas as the result of a meeting of people from different places and cultures, whose process of hybridization and the construction of collective values extends through time, we perceive the primordial fragility that permeates the constitution of a political project at local level that wants to be participatory and democratizing. Although the presence of social movements at a very early stage in the history of the city and its articulation with other movements on a national scale are recognized $^{10}$, what is argued here is the fact that precisely its precocity is reflected in the lack of maturation necessary for its constitution as a field of dispute capable of confronting the neoliberal project which, at the same time as it precedes it, constitutes itself as the cause of its existence. In this way, without the convergence of two well-defined projects, the perverse confluence, as proposed by Dagnino (2004a, 2004b, 2004c) would not even take place, since the political dispute between them is presented as a necessary condition
10 "Dentre os 26 anos de criação de Palmas, 21 anos de sua história são marcados pela presença dos movimentos de moradia" (SUZUKI, 2016, p.82). 
for perversity. However, the effects of the discursive crisis arising from this process are present, reproducing the same displacements of meanings around the notions of participation, civil society and citizenship, through which they obscure differences, dilute nuances and reduce antagonisms. Again, in Palmas, It's possible to observe the incorporation of effects totally disconnected to the processes that constitute them, thus reinforcing the hypothetical condition of the laboratory city discussed previously.

\section{Final considerations}

"O consenso então não é nada mais que a supressão da política"

(RANCIÈRE, 1996, p.379)

For Rancière, disagreement lies at the heart of politics - conceived as a possibility of rupture of order - and presents itself as a fundamental characteristic of public life. However, in the neoliberal city, conflict is understood as something to be eliminated in the name of the common good. The search for consensus then becomes the most appropriate response to the dilemmas of contemporary society, identifying it to political rationality and to the very principle of democracy (Idem, p.367).

In the process of production of the urban space of Palmas, the pacification tendencies are present in the strategies of naturalization of an unjustified socio-spatial segregation, in the location of the conflicts by dwelling in the peripheral zones of the city, established as territory of dispute in contrast to the immense urban voids in the Central areas, strategies of pacification and neutralization of the public sphere, among other factors to be expanded and deepened in the following stages of the present research.

As a conclusion, it should be noted that the city of Palmas is still a field of recent study, full of gaps and processes in an incipient phase of conformation. The approximation of the discussions presented to the reality verified in our exploratory axes passes, mainly, by the necessity of realizing primary surveys and opening of some "doors" still little explored by the academic world in the local context. 


\section{References}

CARLOS, A. F.; SOUZA, M. L.: SPÓSITO, M. (orgs.). A produção do espaço urbano: agentes e processos, escalas e desafios. São Paulo: Contexto, 2013.

CARLOS, A. F. O Espaço Urbano: novos escritos sobre a cidade de São Paulo. São Paulo: Labur Edições, 2007.

DAGNINO, E. Construção democrática, Neoliberalismo e Participação: os dilemas da confluência perversa. In: Política \& Sociedade - Revista de Sociologia Política, 137-161, Florianópolis, v.1, n. 5, 2004a.

DAGNINO, E. Sociedade civil, participação e cidadania: de que estamos falando? In: MATO, Daniel (coord.), Políticas de ciudadanía y sociedad civil en tiempos de globalización, 95110, Caracas: FACES, Universidad Central de Venezuela, 2004b.

DAGNINO, E. Confluência perversa, deslocamentos de sentido, crise discursiva. In: GRIMSON, A. (ed.), La cultura en las crisis latino-americanas, 195-216, CLACSO, Buenos Aires, 2004c.

HARVEY, D. Condição pós-moderna : uma pesquisa sobre as origens da mudança cultural. São Paulo: Edições Loyola, 1992.

HARVEY, D. "Do gerenciamento ao empresariamento: a transformação da administração urbana no capitalismo tardio". In: Revista Espaço \& Debates, 48-64, n.39, 1996.

HARVEY, D. O Enigma do Capital e as crises do capitalismo. São Paulo: Boitempo, 2011.

HARVEY, D. Cidades Rebeldes: do direito à cidade à revolução urbana. São Paulo: Martins Fontes, 2014.

LIRA, E. R. A Gênese de Palmas-Tocantins. A Geopolítica de (Re) Ocupação Territorial na Amazônia Legal. Goiânia: Kelps, 2011.

LIRA, E. R.; CARVALHÊDO, W. S. Palmas ontem e hoje: do interior do Cerrado ao portal da Amazônia. In: Observatorium Revista eletrônica de Geografia, 51-73, v.1, n.2, jul 2009. Disponível em:<http://www.observatorium.ig.ufu.br/pdfs/1edicao/n2/PALMAS\%20 ONTEM\%20E\%20HOJE.pdf> (Acesso em 07 de fevereiro de 2016.)

MARTINS, J. S. O poder do atraso: ensaios de sociologia da história lenta. São Paulo: Hucitec, 1994.

MELLO, N. A.; BERTONE, L. F. Palmas: perfil ambiental e gestão urbana convergem para a sustentabilidade ambiental? In: Mercator Revista de Geografia da UFC. [online], p.72-88, ano 03, n. 6, 2004. 
MIRANDA, B. R. S. A Luta Pela Moradia nas Cidades Brasileiras: História da Ocupação da Quadra 1.306 Sul, em Palmas. Monografia de graduação, Palmas, 2005.

PALACÍN, L. Coronelismo no extremo norte do Goiás: o padre João e as três revoluções de Boa Vista. Goiânia: CEGRAF; São Paulo: Loyola, 1990.

PELÁ, M.C.H.; BARREIRA, C. C. M. A. Goiânia, Brasília e Palmas: Modelos urbanos do projeto de modernização do Cerrado e do território brasileiro. In: Santos, Roberto de S. et al. (orgs.) Território e diversidade territorial no Cerrado: cidades, projetos regionais e comunidades tradicionais. Goiânia: Kelps, 2013.

RANCIÈRE, J. O Dissenso. In: NOVAES, A. (org.) A crise da razão, 367-382, Brasília, Ministério da Cultura. Rio de Janeiro, Funarte: Companhia das Letras, 1996.

RANCIÈRE, J. A Partilha do Sensível. Estética e Política. São Paulo: Editora 34, 2009.

SILVA, M.J.A. Sujeitos em cena: Processo de organização dos movimentos sociais em Palmas/TO 1989/2008. Dissertação de Mestrado apresentada à Universidade Católica de Goiás, 2009.

SILVA, V.C.P. "A cidade no labirinto: descortinando metáforas da pós-modernidade". In: Sociedade \& Natureza, 147-158, 21 (1), Uberlândia, Abril de 2009.

SILVA, V.C.P. Palmas, a última capital planejada do século XX: uma cidade em busca do tempo. São Paulo: Cultura Acadêmica, 2010.

SUZUKI, F. H. As ocupações dos movimentos de moradia em Palmas e a disputa pelo espaço urbano. Trabalho de Conclusão de Curso do curso de Arquitetura e Urbanismo, Universidade Federal do Tocantins, 2016.

TEIXEIRA, L.F.C.; FILHO, W. A. O. O ideal e o real. Entrevista a Hugo Segawa. In: Revista Projeto, 103-108, n. 146. São Paulo: Projeto Editores Associados Ltda., 1991.

TREVISAN, R. Cidades Novas. Tese de Doutorado apresentada à UNB, 2009.

VAINER, C. Os liberais também fazem planejamento urbano? In: ARANTES, O.; VAINER, C.; MARICATO, E. A cidade do pensamento único: desmanchando consensos, 105-119, Petrópolis: Vozes, 2000.

VELASQUES, A.B.A. A última capital planejada do século $X X^{\prime}$ : o projeto de Palmas e sua condição moderna. [online]. Disponível em: <http://www.docomomo.org.br/seminario\%208\%20pdfs/001.pdf> (Setembro 23, 2015). 